\title{
Russian system of preservation of anthropological potential in the face of increasing threat of emergency situations, natural, man-made and terrorist nature
}

\author{
Maksim Kochetkov ${ }^{1,2, *}$, Natalya Karmanovskaya ${ }^{1}$, and Tatyana Sharoglazova ${ }^{3}$ \\ ${ }^{1}$ Norilsk State Industrial Institute, 663310 Norilsk, Russia \\ ${ }^{2}$ Siberian Federal University, 660041 Krasnoyarsk, Russia \\ ${ }^{3}$ Municipal Autonomous educational institution "Secondary School № 82", Krasnoyarsk, Russia
}

\begin{abstract}
The problem of prevention and liquidation of emergency situations, including terrorist acts is investigated. The improvement of weapons and the professionalization of terrorist organizations make it difficult to determine the cause of natural and man-made emergencies. Therefore, the dominance in Russia of the territorial principle of functioning of the unified state system for the prevention and elimination of emergency situations meets the challenges of time less and less. The urgency of mechanisms of extraterritorial mobilization of forces and means of prevention and liquidation of emergency situations is proved. The existing system of prevention and liquidation of emergency situations of natural and man-made character is connected with the key role of the Ministry of emergency situations of Russia. At the same time, the military Department is in charge of responding to emergency situations determined by military threats. It is proposed to change this hierarchy, defining the leading role of the military Ministry.
\end{abstract}

\section{Introduction}

Every year, on the territory of the Russian Federation, emergencies of a man-made, natural, social nature and acts of terrorism occur. The property damage from these emergencies is steadily increasing, as well as the number of affected populations. Such a situation is typical for many countries all over the world [1-3].

The political and military situation remains tense, which is confirmed by the events in Ukraine and Syria and other parts of the planet [4-6].

In Russia, an emergency (ES) is defined as a situation in a certain territory that has developed as a result of an accident, a dangerous natural phenomenon, catastrophe, natural or other disasters that may or may have resulted in loss of life, damage to human health or the environment, significant material losses and violation of living conditions of people.

\footnotetext{
* Corresponding author: $\underline{\text { m-kochetkov@ yandex.ru }}$
} 
This concept is represented in the law entitled «On the protection of the population and territories from natural and man-made emergencies» (Federal law of the Russian Federation of 21 December 1994 № 68). This is the main regulatory legal act and it is the basis for system operation of the preventing and eliminating natural and man-made emergencies.

According to the Russian military doctrine, Russia has no enemies among the other states. The possibility of military threats on the territory of the Russian Federation exists. One of the signs of it is associated with the approach of the military infrastructure of the NATO member countries to the borders of the Russian Federation [7-9]. Hereinafter, military threats will be not the direct military aggression of any country, as much as the terrorist activities of transnational organized crime. Such an assumption seems to be productive, since military clashes with NATO member countries on the territory of the Russian Federation are unlikely against the background of very real terrorist threats.

\section{Research methodology}

In this study, the term "preservation of anthropological potential" is used because the Russian legal and scientific discourse on relevant issues contains essentially similar concepts, for example, "safety" (military, national security, life safety, fire safety, industrial safety), "civil protection" protection of the population and territories", "civil defense". All of them reflect the direction of state activity related to the preservation of the material, natural and human resources of the country, where the human being is the supreme value [10-12].

The term "preservation of anthropological potential" can be called academic, since, unlike the above, it does not appear in regulatory legal act, nor in the methodological recommendations of the security forces devoted to countering man-made, natural, socially destabilizing, military, and terrorist threats. However, in the conditions of significant terminological inconsistency of legally oriented terms, the category "preservation of anthropological potential" is accepted by us as the key one in this study, due to its inclusiveness and capacity. After all, the preservation of anthropological potential implies the elimination of all destructive factors, starting with environmental degradation and ending with man-made, natural and military incidents.

It should be noted that the inconsistency of similar in essence and legally oriented concepts and relevant regulatory legal documents is not confined only to Russia. This is a rather fundamental question, since inconsistency is a sign of a sub-optimal emergency response. Thus, the activities of Russia in addressing issues of integrated security are related to interaction with organizations such as the UN International Strategy for Disaster Risk Reduction (UNISDRR), the International Civil Defense Organization (ICDO), the European Center for New Technologies for Disaster Risk Management and Technological Disasters. The names of organizations to some extent just confirm our conclusion.

\section{Results of the study}

In Russia, civil defense (CD) means a system of measures to prepare for the protection and protection of the population, material and cultural values in the territory of the Russian Federation from the dangers arising in military conflicts or as a result of these conflicts, as well as in the event of natural and man-made emergencies.

The concept of civil defense is represented in the law entitled "On Civil Defense" (Federal law of the Russian Federation of 12 February 1998 № 28). This is the main regulatory legal act for civil defense.

The system of providing civil defense in Russia is headed by the Ministry of Defense (MOD), that is, the military department. 
In the middle of the last century the system for ensuring protection of the population and territories from natural and man-made emergencies is headed by MOD. Currently - another Ministry, the Ministry of the Russian Federation for Civil Defense, Emergencies and Disaster Relief (EMERCOM of Russia).

The protection of the population, material and cultural values and natural resources from military threats is carried out in Russia as part of a system of measures for civil defense. Relevant legislation is quite autonomous. The system of measures to ensure civil defense and the system of measures to protect the population and territories from natural and man-made emergencies are completely independent and self-sufficient. It is obvious that in certain situations it is necessary to combine the forces and means used to provide civil defense and the forces and means used to protect the population and territories from natural and manmade emergencies. In this regard, we note that the system of measures to protect the population and territories from natural and man-made emergencies at a certain level of its operation is designed, if necessary, to ensure the unification of the forces and means of both systems: Regional Department of Civil Defense and Emergencies (Figure 1). It is quite obvious that the functions of the Regional Department of Civil Defense and Emergencies are precisely connected with the above combination of forces and means. Going back to the definition of "emergency", we note that the wording "other disasters" in italics just might imply military, which includes terrorist, threats.

The objectives of civil defense and the tasks of preventing and eliminating natural and man-made emergencies are increasingly forming an integral whole. This tendency, in our opinion, is characterized by steady strengthening. At the same time, the complexity of qualifying the incident as a military (terrorist) will increase, and it will also be increasingly difficult to separate the military causes of emergencies from natural and industrial causes.

For example, according to a number of experts, climate weapons exist and increasingly used in the world. However, its use is difficult to identify, and that has intensified the development of various models of emergency situations [13-17]. As a result, in the case of climate weapons, it is almost impossible to qualify the hostilities outbreak quickly. A similar situation is relevant for other methods of proxy war ("vicarious warfare") [18-21], which were not taken into account in the previous Russian military doctrines. The point at issue is, for example, the impact of information in order to undermine the historical, spiritual and patriotic traditions in the field of the defense of fatherland (Military doctrine of the Russian Federation).

The fundamental importance of the effective differentiation of military causes of emergencies from natural and industrial causes is due to the fact that in Russia the introduction of civil defense as a system of measures throughout the country or in its localities is focused on responding to obvious military (terrorist) actions.

The introduction of the system for providing civil defense begins with:

- The moment of declaration of a state of war;

- The actual start of hostilities;

- The introduction by the President of the Russian Federation of martial law on the territory of the country or its particular locality (Federal law of the Russian Federation of 12 February 1998 № 28-Ф3 «On civil defense».).

According to the Military doctrine of the Russian Federation, one of the external military dangers is the use of information and communication technologies for military and political purposes. This emphasis of the Russian military doctrine is quite adequate to the concept of hybrid warfare, which first appeared in the military documents of the United States and Britain in the early XXI century. Hybrid warfare means the solution of military tasks by means of information, electronic, cyber operations, combined with the actions of the armed forces, special services and intense economic pressure. For our study, it is important that in the implementation of a hybrid war, the attacking side does not resort to the classical military 
invasion, which complicates the decision of state structures to introduce a system of CD. Even if the need for martial law is obvious for state structures, the relevant decision may be delayed due to the fear of pressure from the world's information resources, that is, the possible intensification of the information side of hybrid military actions.

Thus, for example, in the case of use of climate weapons, the consequences are eliminated (at least in the initial stages) not as part of a system of measures for civil defense, but as part of a system of measures to eliminate natural and man-made emergencies. This circumstance can limit the possibility of effective emergency response.

Today, methods of waging of wars (carrying out terrorist acts) that are associated with sabotage, organization and provoking natural and man-made emergencies are becoming more common. In this regard, essential re-thinking the fundamentals of the anthropological potential preservation strategy and providing a qualitatively new system of the corresponding state and administrative activity are growing more urgent.

The outlined range of issues is the subject of this study, which, due to the exceptional complexity of its components, in some cases claims only to designate the most common approaches to solving problems, posing problems as a significant result in itself when solving global issues.

As noted above, despite the similarity of the tasks of civil defense and the tasks of preventing and eliminating emergency situations, they are governed by significantly different regulatory legal acts. In the case of civil defense, natural and man-made emergencies are considered as a consequence of military conflict. If an emergency situation is not related to a military conflict, then the response to it is carried out within the frame of the so-called Unified Emergency Prevention and Response State System (RSChS). The abbreviation RSChS is established in the first paragraph of the Russian Government Resolution No. 794 of December 30 (Resolution of the Government of the Russian Federation of December 30, 2003 № 794). This Resolution is dedicated to a detailed description of the functioning of $\mathrm{RSChS}$. The rather strange discrepancy between the abbreviation and the full the system name is related to the history of the EMERCOM of Russia. In April 18, 1992, a Resolution of the Government of the Russian Federation "On the establishment of the Russian warning system and actions in emergency situations" appeared (Resolution of the Government of the Russian Federation of April 18, 1992 № 261.) Later, on January 10, 1994, the Ministry of Emergency Situations of Russia was formed. The EMERCOM of Russia has significantly improved the emergency response system. The system began to carry the full name of Unified Emergency Prevention and Response State System. At the same time, the old abbreviated name of the system (RSChS) remained.

We have developed a diagram illustrating the functioning of the RSChS (Figure 1). 
The Unified Emergency Prevention and Response State System (RSChS)

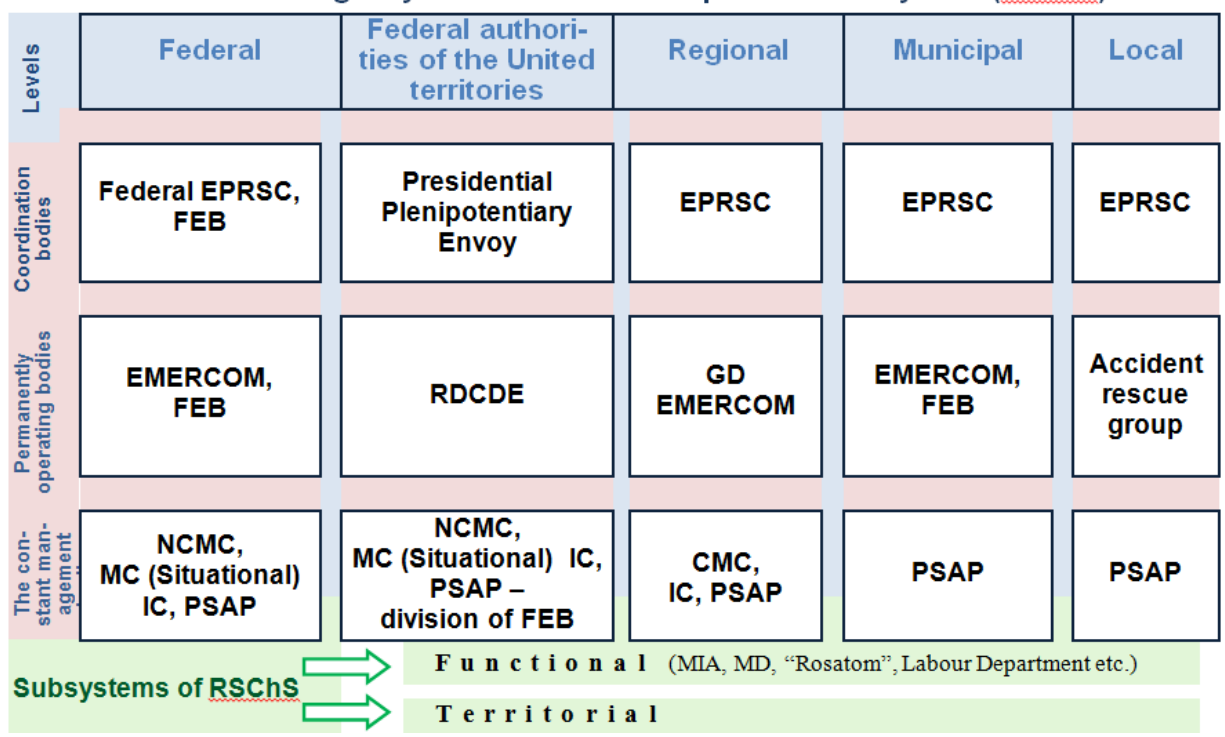

Fig. 1. Generalized scheme of RSChS.

Where: GD - General Directorate;

PSAP -Public Safety Answer Point;

IC - Informational Center;

EPRSC -Emergency Prevention and Response State Committee;

EMERCOM - the Ministry of the Russian Federation for Civil Defense, Emergencies and Disaster Relief;

NCMC - National Crisis Management Center;

RSChS- Unified Emergency Prevention and Response State System;

RDCDE- Regional Department of Civil Defense and Emergencies;

FEB - the federal executive bodies;

$\mathrm{MC}$ - Management Center;

$\mathrm{CMC}$ - Crisis Management Center.

\section{Discussion of the results}

RSChS unites authorities, forces and means of federal executive authorities, executive authorities of the constituent entities of the Russian Federation, local governments and organizations which deal with issues in the field of protecting the population and territories from emergency situations, and carries out its activities in order to accomplish tasks confirmed by the Federal Law "On the Protection of the Population and Territories from Natural and Man-Made Emergencies" (Federal law of the Russian Federation of 21 December 1994 № 68).

RSChSoperatesatthe federal, federal district, regional, municipal and locall levels.

At the same time, RSChS includes functional and territorial subsystems.

Thus, functional subsystems include the functional subsystem of public order protection of the Ministry of Internal Affairs of Russia; such subsystems EMERCOM of Russia as monitoring, laboratory monitoring and forecasting of emergency situations; warning and extinguishing fires; prevention and liquidation of emergency situations at underwater potentially dangerous objects in internal waters and the territorial sea of the Russian Federation; coordinating the search and rescue of people in the internal waters and territorial 
sea of the Russian Federation; functional subsystem of emergency prevention and response of the Armed Forces of the Russian Federation; such subsystems of the Ministry of Health, as the All-Russian Service of Emergency Medicine, medical and sanitary assistance to victims in emergency situations in organizations (facilities) under the jurisdiction of the FMBA of Russia, as well as organizations and territories served by the FMBA of Russia; reserves of medical resources; functional subsystem of social protection of the population affected by emergencies of the Ministry of Labor of the Russian Federation; the functional subsystem for monitoring nuclear and radiation hazardous facilities, as well as monitoring the chemically hazardous and fire and explosion hazardous facilities of Federal Environmental, Industrial and Nuclear Supervision Service of Russiaand many other subsystems of a large range of ministries and departments in Russia.

RSChS management bodies are established at every level of RSChS functioning and include RSChS coordinating bodies, permanently operating RSChS management bodies and constant management bodies of RSChS (Figure 1).

Coordination bodies of RSChS are commissions formed to ensure the coherence of actions of federal executive bodies, executive bodies of constituent entities of the Russian Federation, local governments and organizations in the field of protecting the population and territories from emergency situations and ensuring fire safety (Figure 1).

Permanently operating bodies of the Emergency Response System are the bodies specifically authorized to solve problems in the field of protection of the population and territories from emergency situations at the appropriate level of the Emergency Response System (Figure 1).

The constant management bodies of the RSChS are organizations created by the federal executive authorities, the executive authorities of the constituent entities of the Russian Federation, local governments and organizations to ensure their activities in the field of protecting the population and territories from emergency situations, managing forces and facilities intended and assigned for the prevention and elimination of emergency situations, the exchange of information and the population warning of the emergency situation.

The constant management bodies of the RSChS ensure the coordination of the activities of the RSChS (including the management of forces and means of the RSChS): organizing information interaction between the federal executive authorities, the executive authorities of the constituent entities of the Russian Federation, local governments and organizations when solving problems in the field of protecting the population and territories from emergency situations and civil defense, as well as the implementation of information support for making decisions.

At the federal level, the constant management body (the National Crisis Management Center) is under the jurisdiction of the federal executive body, namely the Ministry of Emergency Situations of Russia. It is authorized to solve tasks in the field of protection of the population and territories from emergency situations, in the manner established by the Government of the Russian Federation.

At the federal district level and regional level, constant management bodies (crisis management centers) are also under the authority of the EMERCOM of Russia.

The functioning of the RSChS is closely related to the assignment of a territory to the group of Civil Defense (special, the first and the second ones); regime of RSChS (daily activities, high alert and emergency); the establishment of one of the response levels (site, local, regional, federal, special levels).

So, in the regime of emergency the following measures are carried out:

- permanent monitoring of the the environment state, monitoring and forecasting the development of emergencies, as well as assessment of their socio-economic consequences; 
- notifying the heads of federal executive bodies, executive bodies of the constituent entities of the Russian Federation, local governments and organizations, as well as the population about the emergency situations;

- carrying out measures for to protect the population and territories from emergency situations;

- organization of work on emergency response and comprehensive support of the actions of $\mathrm{RSChS}$ forces and facilities, maintenance of public order in the course of their conduct, as well as engaging public organizations and the population, if necessary, in the elimination of emergencies;

- continuous collection, analysis and exchange of information on the situation in the area of an emergency situation and in the course of carrying out work to eliminate it;

- organization and maintenance of continuous interaction of federal executive authorities, executive authorities of the constituent entities of the Russian Federation, local governments and organizations on the issues of emergency response and their consequences;

- carrying out activities for the sustenance of the population in emergency situations.

One of the most important for the organization measures on the prevention and elimination of natural and man-made emergencies is the concept of an emergency zone (the territory where the emergency situation has arisen), as the territorial principle of response is designed to optimize the use of forces and means to eliminate emergencies, especially to cope with emergencies in the area in the most effective way. For this, the emergency zone determines the level of response, the volume and nature of the corresponding response means.

The response level is a state of readiness of the authorities and forces of the RSChS, requiring additional measures from the state authorities of the Russian Federation, state authorities of the constituent entities of the Russian Federation, local authorities and organizations to protect the population and territories from emergency situations depending on the classification and the nature of development of emergency situations.

The level of response is determined on the basis of the territorial principle and, as noted earlier, is subdivided into the object level of response, local level of response, regional, federal and special levels of response.

Thus, the local level of response is determined by the decision of the head of the settlement in case of emergency response by the forces and means of organizations and local management bodies appeared in the emergency zone that affects the territory of one settlement.

Not least important for the organization is the concept of the functioning of the management bodies and forces of the RSChS. It is the procedure of activities and measures by the management bodies and forces of the RSChS, which are determined by the results of prediction of the threat and the results of the assessment of the emergencies, carried out by these authorities, with the introduction of high alert or emergency.

The forces and means of each level of the RSChS include forces and means of constant readiness, designed for rapid response to emergency situations and work to eliminate them.

The basis of the forces of constant readiness are emergency services, emergency response units, other services and formations provided with special equipment, tools, materials, taking into account the provision of emergency and rescue and other urgent work in the emergency zone for at least 3 days.

The list of permanent readiness forces of territorial subsystems is approved by the executive authorities of the constituent entities of the Russian Federation in coordination with the EMERCOM of Russia.

The structure of the permanent readiness forces are determined by the federal executive bodies that create them, the executive authorities of the constituent entities of the Russian Federation, local governments, organizations and public associations based on the tasks assigned to them to prevent and eliminate emergency situations. 
Coordination of the activities of the rescue services, rescue teams, public associations involved in carrying out rescue operations and operating in all or most of the territory of the Russian Federation, as well as all types of fire protection is carried out in the prescribed manner by the EMERCOM of Russia.

Coordination of the activities of rescue services and rescue teams in the territories of the constituent entities of the Russian Federation is carried out in the prescribed manner by the main emergency departments of the constituent entities of the Russian Federation.

Coordination of the activities of rescue services and rescue groups in the territories of municipal unit is carried out by bodies specifically authorized to solve tasks in the field of protection of the population and territories from emergency situations and civil defense at local government bodies.

To receive messages about emergencies, including those caused by fires, a single emergency call number " 112 " and the number of fire brigade received by the federal executive authority in the field of communications are used.

Measures for the prevention and liquidation of emergency situations within the frame of RSChS are carried out on the basis of the federal action plan for the prevention and elimination of emergency situations, action plans for the prevention and liquidation of emergencies of federal districts, constituent entities of the Russian Federation, municipal units and organizations.

The organizational and methodological management of the planning of actions in the framework of the Russian Emergencies and Emergencies System is carried out by the Russian Emergencies Ministry

The elimination of emergencies, as well as the functioning of the entire RSChS, is also implemented in accordance with the territorial principle such as:

- elimination of local emergencies is carried out by the forces and means of the organization; - elimination of municipal emergencies is carried out by the forces and means of local authorities;

- the elimination of emergencies of an inter-municipal and regional nature is carried out by the forces and means of local governments, executive authorities of the constituent entities of the Russian Federation, which find themselves in the emergency zone;

- the elimination of emergencies of federal district and federal nature is carried out by the forces and means of the executive authorities of the constituent entities of the Russian Federation that are in the emergency zone.

To eliminate emergency situations are created and used the following types of support:

- the reserve fund of the Government of the Russian Federation for the prevention and elimination of emergency situations and the consequences of natural disasters;

- stocks of material values to ensure urgent work to eliminate the consequences of emergency situations that are part of the state material reserve;

- reserves of financial and material resources of federal executive bodies;

- reserves of financial and material resources of the constituent entities of the Russian Federation, local governments and organizations.

Financial support for the operation of emergency response systems and measures for the prevention and elimination of emergencies is carried out at the expense of the relevant budgets and property owners (users) in accordance with the legislation of the Russian Federation. Organizations of all forms of ownership are also involved in emergency response but at their own expense.

In case of insufficiency of forces and means, forces and means of the federal executive bodies are attracted in accordance with the established procedure. In other words, the system of measures of the emergency system allows an extraterritorial approach to emergency response. 
As noted, the detailed functioning of RSChS is reflected in the RF Government Decree of 30.12.2003 No. 794. Considering the described, in our opinion, the most essential features of the functioning of the emergency system, the relevance of effective disaster prediction becomes clear. Forecasting of emergency situations is carried out on the basis of a number of methods [22-26], including methods on the basis of risk indicators (State standard $\mathrm{R}$ 22.0.02-94) and the results of environmental monitoring. Theresultsofthe prediction form the basis of almost all aspects of the operation of the RSChS: the allocation of resources to reduce various factors of occurrence of emergency situations, the accumulation of resources and their territorial concentration in order to achieve an acceptable level of public safety and the environment, etc. We especially focus on the relevance of effective forecasting of emergencies in connection with the calculation of probable emergency areas, which determines the entire process of responding to emergencies, ultimately the effectiveness of preventing and eliminating emergencies.

All emergencies are classified into conflict-free and conflict, that is, resulting from the clash of religious, ethnic and other interests of different social groups, military (terrorist) acts. It is quite obvious that the applied probable and frequent estimates of natural and man-made emergencies based on risk indicators and long-term environmental monitoring are not acceptable in the case of several planned terrorist acts at industrial enterprises in different regions, or as a result of the use of climate weapons. Given the increasing likelihood of "conflict" emergencies, the extraterritorial response to emergencies, that is, "with a reserve" response, becoming more urgently attracting forces and funds, including from other territories, based on the most severe scenario of development of an emergency or number of Emergencies, including the other territories as a result of intensified terrorist activities.

\section{Conclusion}

Thus, the relevance of the study is due to the steady growth emergency situations of manmade, natural, social nature, and terrorist acts in the world, and in Russia as well. At the same time, the increasing probability of emergency situations deserves special attention, the scale and occurrence of which is difficult to predict because of the conflict nature of their origin and improving ways of conducting hybrid warfare, as well as non-traditional weapons (for example, climate weapons).

Thiscircumstanceimpliesthe provision of a more combined application of the territorial principle of functioning of the emergency system. This refers to the improvement of procedures for extraterritorial emergency response so that there are more opportunities to mobilize forces and means, including from other territories, quickly and with a substantial reserve to eliminate emergency situations and enhance emergency prevention measures in regions with normal conditions (based on potential connection of emergency situations with terrorist activity, its possible implementation in several places).

To do this, it is necessary, taking into account modern operational and technological capabilities of weapons and the professional potential of terrorist groups, to develop an adequate system for monitoring, analyzing and forecasting emergencies; emergency warning system; emergency response system, including rapid response to emergencies, as well as emergency rescue, life support and rehabilitation technology for the affected population; a system of training government bodies, specialists and the public in the field of prevention and elimination of emergency situations, as well as solving civil defense problems.

In connection with what has been said, planning methods, established systems of administrative, managerial and material and technical measures, and collection and analysis of environmental data are in need of serious processing. A qualitatively different level of professionalism of the units responsible for the daily functioning of the emergency system is relevant (Figure 1). 
It is obvious (Figure 1) that the Ministry of Defense and other security agencies should play a more significant role in monitoring and analyzing emergency situations, the daily operation of the Emergency Response System, and the use of emergency forces and means. In this regard, focus attention that in the USSR the civil defense system was protecting the population and territories when conducting military operations, as well as against natural, man-made and social emergencies. In other words, Ministry of Defense played the key role, which cannot be said about the functioning of the Emergency Response System. We believe that a return to the practice of the past, but at a qualitatively new level, is advisable in the very near future. Such modernization of the RSChS is more adequate to modern technological and tactical capabilities of military, man-made and terrorist threats. This is due, in particular, to the fact that at present the declaration of martial law in the event of non-military emergencies is very problematic, although the preservation of the country's anthropological potential should be the highest priority.

\section{References}

1. J. Argomaniz, O. Bures, C. Kaunert, Intelligence and National Security, 30 (2-3), 191 (2015)

2. B.A. Van Asselt Marjolein, Contemporary Security Policy, 39 (4), 590 (2018)

3. T.A. Marks, P.B. Rich, Small Wars \& Insurgencies, 28 (3), 409 (2017)

4. F. Doeser, J. Eidenfalk, Contemporary security policy, 40 (1), 4 (2019)

5. T. Libel, Defence studies 16 (2), 137 (2016)

6. R. Schwab,Small Wars \& Insurgencies 29 (4) 801-826 (2018)

7. J. Becker Defense \& security analysis 33 (2) 131 (2017)

8. J. Zając, Poland's security policy: the West, Russia, and the changing international order (London: Palgrave Macmillan, 2016)

9. D. Majumdar, The National Interest (2016), http://nationalinterest.org/blog/thebuzz/americas-master-plan-defend-europe-russian-aggression-15176

10. M. Kochetkov, Art and Intercultural Communication 375 (2015)

11. M.V. Kochetkov, I.A. Kovalevich, Journal of Siberian Federal University. Humanities and Social Sciences 13 (2) 268 (2020)

12. M.V. Kochetkov, E.A. Avdeeva,International Journal of Criminology and Sociology. 9 2813 (2020)

13. J.L. Coen, M. Cameron, J. Michalakes, E.G. Patton, P.J. Riggan, K.M. Yedinak, Journal of Applied Meteorology and Climatology 52 (1) 16 (2013)

14. W.E. Heilman, Y. Liu, S. Urbanski, V. Kovalev, R. Mickler Forest Ecology and Management 31770 (2014)

15. R.R. Linn, K. Anderson, J. Winterkamp, A. Brooks, M. Wotton M, I.L. Dupuy , Canadian Journal of Forest Research 42(5) 879 (2012)

16. J.Reisner, G. D’Angelo, E. Koo, W. Even, M. Hecht, E. Hunke, Journal of Geophysical Research Atmospheres 1232752 (2018)

17. O.B. Toon, R.P. Turco, A. Robock, C.Bardeen,L. Oman. G.L. Stenchikov G L, Atmospheric Chemistry and Physics 7 (8) 1973 (2007)

18. S. Brown, Small Wars \& Insurgencies 27243 (2016)

19. T. Waldman, Contemporary Security Policy 39 (2) 181(2018)

20. S. Recchia, Security Studies 24 (2) 251 (2015) 
21. A. Chong Journal of Strategic Studies 38 (3) 233 (2015)

22. D.A. Kalashnikova, M.V. Kabanov, V.N. Melkov, G.V. Simonova G V, IOP Conf. Series: Earth and Environmental Science 211 (2018)

23. V.V. Argunov, R.R. Karimov, V.A. Mochalov, IOP Conf. Series: Earth and Environmental Science 211 (2018)

24. P.A. Karpushin, N.P. Krasnenko, Yu. B. Popov, A.I. Popova, K.Yu/ Popova, A.S. Rakov, D.S. Rakov, IOP Conf. Series: Earth and Environmental Science 211 (2018)

25. C.L. Reddington, G. McMeeking, G.W.Mann, H. Coe, M.G. Frontoso, D. Liu, Atmospheric Chemistry and Physics 13 (9), 917 (2013)

26. Y. Wu, X. Wang, J. Tao,R. Huang, P. Tian, Atmospheric Chemistry and Physics 17 (12) 7965 (2017) 